\title{
Improved Agricultural Innovations and Women's Empowerment: Multi- dimensionality of Empowerment and Program Evaluation Approach
}

ISSN: 2637-7659

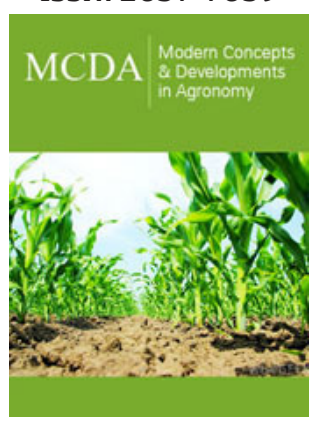

*Correspondingauthor: Tsegaye Mulugeta Habtewold, Department of Economics, College of Business and Economics, Arsi University, Assela, Ethiopiao

Submission: 海 May 24, 2021

Published: 海June 22, 2021

Volume 9 - Issue 1

How to cite this article: Tsegaye Mulugeta Habtewold. Improved Agricultural Innovations and Women's Empowerment: Multi-dimensionality of Empowerment and Program Evaluation Approach. Mod Concep Dev Agrono. 9(1). MCDA. 000701. 2021. DOI: 10.31031/MCDA.2021.09.000701

Copyright@ Tsegaye Mulugeta Habtewold. This article is distributed under the terms of the Creative Commons Attribution 4.0 International License, which permits unrestricted use and redistribution provided that the original author and source are credited.
Tsegaye Mulugeta Habtewold*

Department of Economics, College of Business and Economics, Arsi University, Assela, Ethiopia

\begin{abstract}
Improved agriculture technologies are key factors to better increase welfare, especially in agricultural sector, where most of the population in developing countries suffer from high workload and little returns. On the other hands, the role of Women in agriculture is significant. Several empirical literatures indicate that adoption of agricultural technologies can affect welfare positively in general, but because of its complex and multidimensional nature women's empowerment was not brought to the agenda in program evaluation context in many cases. The current review provides a general overview of connection between improved agricultural technologies and women's role in agriculture. It also explores how the measurement of women's empowerment is one of the challenges in women's study.
\end{abstract}

Keywords: Agricultural technologies; Women's empowerment; Welfare; Program evaluation; Multidimensional

\section{Introduction}

Growing concerns indicate that women's empowerment is increasingly being viewed as one of the key constituent elements of poverty reduction strategy. It is not only seen as a development objective in itself but as a means of promoting growth, reducing poverty and promoting better governance [1]. The role of women's empowerment and its analysis has received a growing amount of attention in research [2]. The MDG\#3 is not only goals in itself but has also contribution in improving productivity and increasing efficiency of women and it is also a priority embedded in the Sustainable Development Goals (SDGs) in 2012 [3] as "Achieve gender equality and empower all women and girls" (SDG\#5).

Evidence also indicates that the role of Women in agriculture is significant, such that they produce over $50 \%$ of the world's food [4] and comprise about $43 \%$ of the agricultural labor force, both globally and in developing countries [5]. Women invest as much as ten times more of their earnings than men do in their family's well-being, in areas including child health, education and nutrition [6-11]. Women's empowerment thus has a direct impact on agricultural productivity and household food security [12-15], and as a result it remains at the core of agricultural research and outreach practices in developing countries [16].

\section{Concepts and Measurement of Women's Empowerment}

The very notion and concept of empowerment is related to issues like agency, autonomy, self-direction, self-determination, liberation, participation, mobilization and self-confidence $[17,18]$. There exist large growing documentation and literature on the concepts and measurements of empowerment, see [17] and [19-22]; and most of these recent studies 
attempt to develop multiple indicators as empowerment is a multidimensional issue and complex process by its very nature that can be conceived and interpreted differently by different people, for example [23,24].

There are many different definitions of empowerment, but majority of these literatures emphasize on agency and gaining the ability to make meaningful choices [20]. Many of the definitions are draw on [25] concept of an agent. Kabeer's study "resources, agency, and achievements" framework also provide a practical intuition for measuring empowerment, which involves three interrelated dimensions; namely resources (pre-conditions), agency (process) and achievements (outcomes) [19] and in this regard Kabeer conceived empowerment as a process that enables individuals/ groups to exercise range of available choice. In the study of empowerment literature three definitions that are commonly cited are found in $[17,20,26]$.

[20] defines empowerment as expanding people's ability to make strategic life choices, particularly in conditions where this ability had been denied to them. [21] describes empowerment as "a groups or individual's capacity to make effective choices, that is, to make choices and then to transform those choices into desired actions and outcomes, [21]." [26] defines empowerment as "the expansion of assets and capabilities of poor people to participate in, negotiate with, influence, control, and hold accountable institutions that affect their lives".

In the context of agriculture, very little is known about the connection between women's empowerment and impacts of improved agricultural innovations in rural society. Women who are empowered tend to be more educated and have a greater level of decision-making power within their household. Some studies have found that women are more likely than men to invest in goods that will benefit their children and households, especially in health and education of their family $[10,11]$. Closing the access and availability of technology gap between women and men requires that the necessary technologies exist to satisfy the priority needs of female farmers, given that women are aware of their usefulness and have the means to acquire them [4]. A paperwork by [27] in their study a qualitative assessment of gender and irrigation technology in Kenya and Tanzania have found that women can benefit from adoption of a technology even if they do not have recognized ownership in their household, while [28] argues that labor or time saving improved agricultural technologies can improve working method in the agriculture sector for women and increase women's earnings.

Women make essential contributions to economic and social development, but in many countries, they benefit less from what is produced. Closing gender gaps and empowering women should be a key target for policy makers aiming to alleviate poverty and make growth more inclusive. Highlighting the current constraints faced by many African countries, for example a study by [29] showed that while women in rural Ethiopia are more likely to spend their income on their families' wellbeing compared to men, they have limited access to land and tenure security, and are less likely to receive education, training, and access to credit.

\section{Observed Gaps in Women's Study in Agriculture and Solutions}

In contrast to the large literature in measuring women's empowerment, its association with factors like food security [3032], child nutrition [33-35], or overall nutrition [36], research on how agricultural innovations influence women's empowerment is very sparse. A deep literature search in the field indicates that only a single study by [37] explored the effects of seed improvement and seed governance on women's empowerment in Syria and found that participation in seed breeding programme enhanced the empowerment of the respondent women. The study also indicated that gender-blind improved seed management system nationally significantly limited the empowerment of these women eventually affecting the different components of food security.

It is also important to develop indicators for measuring women's empowerment, to examine its relationship to various welfare outcomes or indicators, and to effectively monitor the impact of interventions in the agricultural related sectors to empower girls and women.

\section{Conclusion}

The complex and multidimensional nature of empowerment makes its measurement more difficult [2], and especially this is true in the context of agriculture, where the concept is relatively new. Again, the nature and extent of gender disparity and means of empowering women vary across countries, communities and regions in general. As the majority of indexes and indicators used in monitoring programs on gender equity have little coverage of the agricultural sector, whereas many agriculture-related indicators are gender-blind [37], there is a clear need for a tool to measure and monitor the impact of agricultural interventions on empowerment of women within the agricultural sector [29].

Overall, the vast literature in the area shows that there exists methodological gaps and limitations in measurement of women empowerment in the agricultural sector. There are also gaps in literature on which dimensions of women's empowerment in agriculture drives the process of empowerment due to the adoption of improved agricultural innovations which calls for further studies in the area.

\section{References}

1. World Bank (2001) Engendering development: Through gender equality in rights, resources and voices. Oxford University Press.

2. Alkire S, Meinzen Dick R, Peterman A, Quisumbing AR, Seymour G, et al. (2013) The Women's empowerment in agriculture index. World Development 52: 71-91.

3. United Nations (2015) Transforming our world: The 2030 agenda for sustainable development. United Nations, New York, USA.

4. FAO (2011a) The state of food and agriculture 2010-2011. Women in agriculture: Closing the gender gap for development. Rome, Italy.

5. Doss C (2014) If women hold up half the sky, how much of the world's food do they produce? In: Quisumbing AR, Meinzen Dick R, Raney TL, Croppenstedt A, Behrman JA, Peterman A (Eds.), Gender in Agriculture, Springer, Netherlands. 
6. Duflo E (2012) Women empowerment and economic development. J Econ Lit 50(4): 1051-1079.

7. Quisumbing AR, Maluccio JA (2000) Intrahousehold allocation and gender relations: new empirical evidence from four developing countries. IFPRI, Washington DC, USA.

8. Quisumbing AR, Maluccio JA (2003) Resources at marriage and intrahousehold allocation: Evidence from Bangladesh, Ethiopia, Indonesia, and South Africa. Oxford Bulletin of Economics and Statistics 65(3): 283-327.

9. Quisumbing AR (2003) Household decisions, gender, and development: A synthesis of recent research. IFPRI, Washington DC, USA.

10. Quisumbing AR, Hallman K (2003) Marriage in transition: Evidence on age, education, and assets from six developing countries. Policy Research Division Working Paper 183. Population Council.

11. Skoufias E (2005) PROGRESA and Its Impacts on the Welfare of Rural Households in Mexico. Research Report 139. IFPRI, Washington DC, USA.

12. Sraboni E, Malapit HJ, Quisumbing AR, Ahmed AU (2014) Women's empowerment in agriculture: What role for food security in Bangladesh? World Development 61: 11-52.

13. Harper S, Zeller D, Hauzer M, Pauly D, Sumaila UR (2013) Women and fisheries: Contribution to food security and local economies. Marine Policy 39: 56-63.

14. Bob U (2002) Rural African women, food (in) security and agricultural production in the Ekuthuleni land redistribution project, KwaZuluNatal', Agenda: Empowering Women for Gender Equity 51: 16-32.

15. Galie A (2013) Empowering women farmers. The case of participatory plant breeding in ten Syrian households'. Frontiers: A Journal of Women Studies 34(1): 58-92.

16. Gates MF (2014) Putting women and girls at the center of development. Science 345: 1273-1275.

17. Narayan Parker D (2005) Measuring empowerment: Cross-disciplinary perspectives. World Bank, Washington, DC, USA.

18. Ibrahim S, Alkire S (2007) Agency and empowerment: A proposal for internationally comparable indicators. Oxford Development Studies 35(4): 379-403.

19. Kabeer N (1999) Resources, agency, achievements: Reflections on the measurement of women's empowerment. Development and Change 30(3): 435-464.

20. Kabeer N (2001) Reflections on the measurement of women's empowerment-theory and practice, Discussing Women's EmpowermentTheory and Practice, Novum Grafiska AB, Stockholm, Sweden.

21. Alsop R, Bertelsen M, Holland J (2006) Empowerment in practice. From analysis to implementation, Washington, DC, USA.

22. Alsop R, Heinsohn N (2005) Measuring empowerment in practice: Structuring analysis and framing indicators. World Bank Policy Research Working Paper No. 3510.
23. Malhotra A, Schuler SR, Boender C (2002) Measuring Women's empowerment as a variable in international development.

24. Mosedale S (2005) Assessing women's empowerment: Towards a conceptual Framework. Journal of International Development 17(2): 243-257.

25. Sen A (1989) Co-operation, inequality, and the Family. In: McNicoll G, Cain M (Eds.), Rural Development and Population: Institutions and Policy, Oxford University Press, New York, USA.

26. Narayan D (2002) Empowerment and poverty reduction. World Bank, Washington DC, USA.

27. Njuki J, Waithanji E, Sakwa B, Kariuki J, Mukewa E, et al. (2014) A qualitative assessment of gender and irrigation technology in Kenya and Tanzania. Gender, Technology, and Development 18(3): 303-340.

28. Doss CR, Bockius Suwyn Z, Souza SD (2012) Women's economic empowerment in agriculture: Supporting women farmers. UN Foundation, Washington DC, USA.

29. Habtewold TM (2020) Agricultural technologies and women's empowerment in rural Ethiopia: Do Improved Agricultural Technologies Matter? Selected Poster presentation at the 2020 annual conference of the Inclusive growth in Mozambique programme, 2-6 November 2020 on Zoom- scaling-up research and capacity, organized by the UNUWIDER.

30. Galiè A, Teufel N, Girard AW, Baltenweck I, Dominguez Salas P, et al. (2019) Women's empowerment, food security and nutrition of pastoral communities in Tanzania. Global Food Security 23: 125-134.

31. Clement F, Buisson MC, Leder S, Balasubramanya S, Saikia P, et al. (2019) From women's empowerment to food security: Revisiting global discourses through a cross-country analysis. Global Food Security 23: 160-172.

32. Kassie M, Fisher M, Muricho G, Diiro G (2020) Women's empowerment boosts the gains in dietary diversity from agricultural technology adoption in rural Kenya. Food Policy 95: 101957.

33. Jones R, Haardörfer R, Ramakrishnan U, Yount KM, Miedema S, et al. (2019) Women's empowerment and child nutrition: The role of intrinsic agency. SSM-Population Health 9: 100475.

34. Deutsch J, Silber J (2019) Women's empowerment and child malnutrition: The case of Mozambique. South African Journal of Economics 87(2): 139-179.

35. Abreha SK, Zereyesus YA (2020) Women's empowerment and infant and child health status in sub-saharan africa: A systematic review. Matern Child Health J 25(1): 95-106.

36. Gupta S, Pingali P, Pinstrup Andersen P (2019) Women's empowerment and nutrition status: The case of iron deficiency in India. Food Policy 88: 101763.

37. Galiè A, Jiggins J, Struik PC, Grando S, Ceccarelli S (2017) Women's empowerment through seed improvement and seed governance: Evidence from participatory barley breeding in pre-war Syria. NJASWageningen Journal of Life Sciences 81: 1-8. 